Right to choose? Although private US clinics allow parents to decide the sex of their child, little work has been done on what this means for the family.

he does not offer social sex selection at his clinic because it contradicts the idea that a child should be unconditionally loved, regardless of its sex. "It undermines the principles of the parent-child relationship," Brzyski says.

The United States does not regulate social sex selection, but in the past few years two professional societies, the American Society for Reproductive Medicine (ASRM) and the American College of Obstetricians and Gynecologists (ACOG), have issued statements opposing it.

A spokesman for the ASRM, Sean Tipton, says that the society has no comment on the trial that Carson is running. However, Tipton says, "we can sanction and remove members who don't obey ethics statements."

Carson thinks her study, which will look at the health of the babies born as well as social factors in the families as the children grow up, could convince the ASRM and ACOG to revise their position.

${ }^{\alpha}$ Their statements are based on public opinions, not outcomes," Carson said at the ASRM meeting in Montreal on 18 October. "Public opinion is important, but it shouldn't be used to ban something."

Erika Check

\section{Europe revamps visa rules to attract world's best minds}

The red tape hampering researchers who want to do science in the European Union (EU) has been trimmed. A directive passed this month aims to make it faster for non-EU scientists to get the visas they need.

The move is part of a drive to make the EU more competitive as a knowledgebased economy compared with fastgrowing regions such as Asia. "One way to do this was to make it easy for researchers from around the world to work in the EU," says Georges Bingen at the European Commission's mobilitydirectorate.

At the moment, scientists from non-EU countries such as India, China or Iran can strugglefor months to secure a visa. The new directive fast-tracks applications from researchers wanting to work for more than three months in an EU country. These 'scientist visas' will also allow researchers working in a Schengen country - one of 15 European states that have abandoned passport control between their borders - to work in other Schengen countries during their stay.

Research organizations will be central to arranging visas by certifying the status of guest researchers in formal hosting agreements, instead of leaving scientists to fight with consulates on their own.

Some research organizations, such as Germany's Max Planck Society, already have departments that help foreign visitors with their visas. "Without help from a hosting institution, non-EU scientists can wait up to a year for a visa, and sometimes arrive with the wrong papers," says Ellena Kempe, who runs the International Office at the Max Planck Institute of Molecular Cell Biology and Genetics in Dresden. The new directive should reduce the number of problems, although it won't affect security checks on scientists from politically sensitive countries.

EU ministers have also approved a recommendation to speed up short-term visas for non-EU scientists coming to meetings. "We have heard about Chinese researchers, for example, wanting to attend a meeting in Paris and finding the visa procedures so long and time-consuming that they couldn't attend," says Bingen. Alison Abbott 